Discourse and Communication for Sustainable Education, vol. 10, no. 1, pp. 63-80, 2019

\title{
Sustainable Learning Levels of High School Students
}

\author{
Menekşe Eskici \\ Kırklareli University, Kırklareli, Turkey
}

\begin{abstract}
The aim of this study was to determine sustainable learning levels of students. The study also attempted to determine sustainable learning levels of students based on gender and grade. The participants of the study consisted of 742 high school students (354 females and 388 males) in various high schools in Babaeski district of Kirklareli, Turkey during the 2017-2018 academic year. In order to collect data, a scale with two subscales behavioural and cognitive - was developed. The data were analysed through SPSS 17, and arithmetic mean, standard deviation, t-test and one-way analysis of variance (One Way Anova) were used. According to the results of the study, it is concluded that sustainable learning level of the high school students is moderate. The study also found a significant variation in favour of the female students in "learning for development" subdimension on the cognitive subscale of the scale.
\end{abstract}

Keywords: sustainable learning, high school students, gender.

\section{Introduction}

Production increase thanks to the abundance of technological opportunities and labour has brought a directly proportional increase in consumption. As is the case with the consumption of physical objects like food, clothing, and furniture, the consumption of spiritual concepts like friendship, loyalty, love, is also increasing very rapidly. In a world of fast production and consumption, people's satisfaction in life and their happiness have become a subject of inquiry. As a solution to this problem, the concept of sustainability has emerged. In a society with rapidly growing consumption, it is indispensable to put into implementation the concept of sustainability

The concept of sustainability is addressed in the literature with its different aspects in diverse areas. As a complex concept with environmental, economic and social dimensions in particular (Palmberg et al., 2017; Iliško, 2007; Salìte, 2008), sustainability is defined as an innovation or practice that becomes long term and institutionalized (Balc1, 2010). The concept is often used along with the concept of development as "sustainable development". However, sustainable development cannot be achieved through technological solutions, political arrangements or financial instruments only (Strachan, 2018). To create change in people's attitudes and behaviours, it is of importance to integrate the sustainable development of education at all levels from early childhood to higher education, learning in the workplace, and even to technical and vocational education 
and training (Dash \& Mohan, 2017). People learn whatever they happen to experience and behave according to what they learn. Therefore, the meaning of learning is embedded in the meaning of life (Hargreaves \& Fink, 2006), and there is neither limit nor lack of time for learning throughout an individual's life.

Learning society is defined as the most important value of the future as knowledge is considered a country's most valued asset and primary source of power (Charungkaittikul \& Henschke, 2014). Social norms arise from the cooperation between teachers and students (Mullins, 2018). Pre-service training that teachers receive to perform their profession becomes unnecessary at some point (gains for old school) or insufficient at other points (gains for the future). Here, in-service training comes into play to solve this conundrum. As is stressed by Kabadayı (2016), in-service training is part of sustainable education in society. It is sine quo non for sustainable education (Anyolo, Kärkkäinen, \& Keinonen, 2018; Reid \& Horváthová, 2016). Employees need to learn consistently on every occasion, to become successful in their profession. Individuals who develop themselves in learning whenever possible are those who have developed these sustainable learning skills.

In the future, the world will allow people who learn in a sustainable way to become successful in their profession and happy in their life (Artemeva, 2014). As knowledge acquired for professional and personal development is updated constantly, people always need to learn by refreshing their experiences repeatedly throughout their lives (Rorty, 1989). In this context, as is the case with lifelong learning that arises from a human endeavour to renew and develop constantly (Lambeir, 2005); learning can be accepted as a natural tendency to continue to mature and develop (McCombs, 1991; Pahad, 2012). Increased knowledge and changes in the current situation require people to learn and update their existing knowledge consistently to become successful in personal and professional life. Discussions since the beginning of the century and millennium on sustainability seem like a motivation to reach perfection. There are numerous voluntary activities related to sustainability and its development (Ipiranga \& Aguiar, 2014). Sustainability is a multidimensional topic with multiple actors (politicians, entrepreneurs, environmentalists, academics, and citizens), multiple factors (economic, social, environmental, or cultural) and multilevel impacts and processes (micro, meso, and macro) (Palma \& Pedrozo, 2015). In essence, the concept of sustainability means that something continues for a long time or becomes a permanent activity (Raji \& Zualkernan, 2016). In this respect, the sustainability of learning can be described as continuing learning activity over a lifetime, having no break in learning, and achieving efficient learning by using what is learned in diverse ways as necessary.

It is stated that the concept of sustainable learning drives, cares for and engages students intellectually, socially and emotionally (Hargreaves \& Fink, 2003). The main aim of all educational activities is to ensure that students learn through practising and experiencing, and hence, they use what they have learned during their entire life through transfer (Alberici \& Di Rienzo, 2014). Thus, it is vital that individuals as part of society grow up to be sustainable learners, no matter under what circumstance(s) they live (primitive or modern). A review of the literature on sustainable learning indicated that sustainable learning revolves around four basic principles:

1. Deep and Broad Learning: Deep and broad learning is about learning details as well as related concepts together, the use of learning opportunities when they arise, and creating opportunities for learning as much as possible (Har- 
greaves \& Fink, 2006). Marton and Saljo (1976) consider deep learning as understanding the content and having a holistic insight. Interdisciplinary and multidimensional learning is a must for deep and broad learning to achieve sustainability in education (Warburton, 2003). In addition, being a lifelong learner serves to achieve sustainable learning, because lifelong learning also involves deep and broad learning (Franzenburg, 2017; Blewitt, 2004).

2. Learning through transfer: Transferring is described as applying what is learned to a different situation, associating such learning with daily life and establishing links with diverse examples. Transferring refers to having a multidimensional perspective toward events, developing strategies by using what is learned, creating something new, developing social skills and thinking flexibly (Pepper \& Wildy, 2008). Tractenberg, FitzGerald \& Collmann (2017) specify that transfer is indispensable for sustainable learning. Sustainability is a way of "transferring" the knowledge and ideas learned, so it addresses the problem of unsustainability (Hargreaves \& Fink, 2006). Meaningful learning enhances thinking skills. Critical thinking and questioning the existing knowledge help to transfer and sustain what is learned (Wals \& Jickling, 2002).

3. Learning through dissemination: It explains learning through sharing and disseminating what is learned to convey content to other people and future times, and thus, helping to create a culture (Alberici \& Di Rienzo, 2014; Hargreaves \& Goodson, 2006; Hipp, Huffman, Pankake, \& Olivier, 2008). The specifics of developing sustainable learning cultures for teachers and students need to be determined (Hipp, Huffman, Pankake, \& Olivier, 2008). After all, the continuity of educational changes (that is important, disseminated and sustained) can be addressed only by analysing the experiences of change during the course of such change (Hargreaves \& Goodson, 2006).

4. Learning by thinking ahead: It means that individuals decide what they will learn by considering the future (Pepper \& Wildy, 2008). Due to rapid developments, what students are taught at school can become irrelevant and useless in their future lives. To prevent it, what they learn now must also benefit them in the future.

\section{Method}

Based on the aforementioned four basic principles for sustainable learning, the researchers developed a "Sustainable Learning Scale” which was used to assess students' sustainable learning level. The study also addresses whether students' sustainable learning level varies based on school type, gender and grade.

\section{Participants}

The participants of the study consisted of (354 females and 388 males) 742 high school students in diverse high schools $\left(190\right.$ students in $9^{\text {th }}$ grade, 182 students in $10^{\text {th }}$ grade, 211 students in $11^{\text {th }}$ grade and 159 students in $12^{\text {th }}$ grade) in Babaeski district of Kurklareli, Turkey during the 2017-2018 academic year. 


\section{Data Collection Tool}

To collect research data, the study used the "Sustainable Learning Scale" [SLS] developed as part of the research endeavour. The Sustainable Learning Scale consists of two subscales: behavioural subscale comprising 28 items and cognitive subscale comprising 18 items. A pilot scale was administered to high school students in various grades in different high schools in Babaeski, Kirklareli during the 2017-2018 academic year. The data collected was tested for reliability and validity through SPSS 17 . According to the results of the analysis, the final version of the sustainable learning scale consisted of the behavioural subscale including 15 items and 3 subdimensions, and cognitive subscale including 12 items and 2 subdimensions.

The first subdimension of the behavioural subscale is called "broad and deep learning" and comprises 6 items. The second subdimension of the behavioural subscale is called "learning by applying" and contains 5 items. Since it was considered that the items in this subdimension were related to students' ability in applying what they learn at school in life, this subdimension is called "learning by applying". Another subdimension on this subscale is "learning by updating" that includes 4 items. The items in this subdimension represent student actions to refresh constantly what they learn and update their existing knowledge. The scale was also tested for reliability, and the following results (the Cronbach's alpha values) were found: .85 for "broad and deep learning", .88 for "learning by applying", .90 for "learning by updating" and .89 for the entire behavioural subscale. Results of the analyses demonstrate that behavioural subscale is a reliable and valid data collection tool. Considering that the final version of the behavioural subscale is composed of 15 items and is a 5 Likert-type scale, the highest score on this subscale is 75 while the lowest score is 15 . To test the accuracy of the 3 -factor structure obtained from EFA, the study performed Confirmatory Factor Analysis (CFA) based on structural equation model, which is given in Figure 1.

The result of the analysis revealed that fit indices of the values obtained for model fit were $\mathrm{X} 2 / \mathrm{df}=3.365, \mathrm{TLI}=.920, \mathrm{CFI}=.933$ and $\mathrm{RMSEA}=.056$. In the literature, $\mathrm{X} 2 / \mathrm{df}$ is accepted below 5. Usually, .90 and above is interpreted as good for TLI and CFI while a RMSEA value between .050 and .080 represents good fit (Brown, 2006; Browne \& Cudeck, 1993; Sümer, 2000)

The first subdimension on the cognitive subscale was named "learning for development" and included 8 items. It is evident that the items in this subdimension refer to students' learning activities aimed at self-development. The second subdimension in the cognitive subscale was "learning not for passing exams only" and comprised 5 items. Since it was assumed that the items on this subdimension were related to the students' perception of learning as an action undertaken to pass the exams, the subdimension was named "learning not for passing exams only". The scale was also tested for reliability and the following Cronbach's alpha values were obtained: .88 for "learning for development", .86 for "learning not for passing exams only", and .91 for the entire cognitive subscale. According to the analysis results, the cognitive subscale is a valid and reliable data collection tool. Considering that the final version of the subscale consists of 8 items and is a 5-point Likert type scale, the highest and lowest scores on this subscale are 40 and 8 , respectively.

To test accuracy of the 2-factor structure obtained from EFA, the study performed CFA based on structural equation model, which is given in Figure 2. 

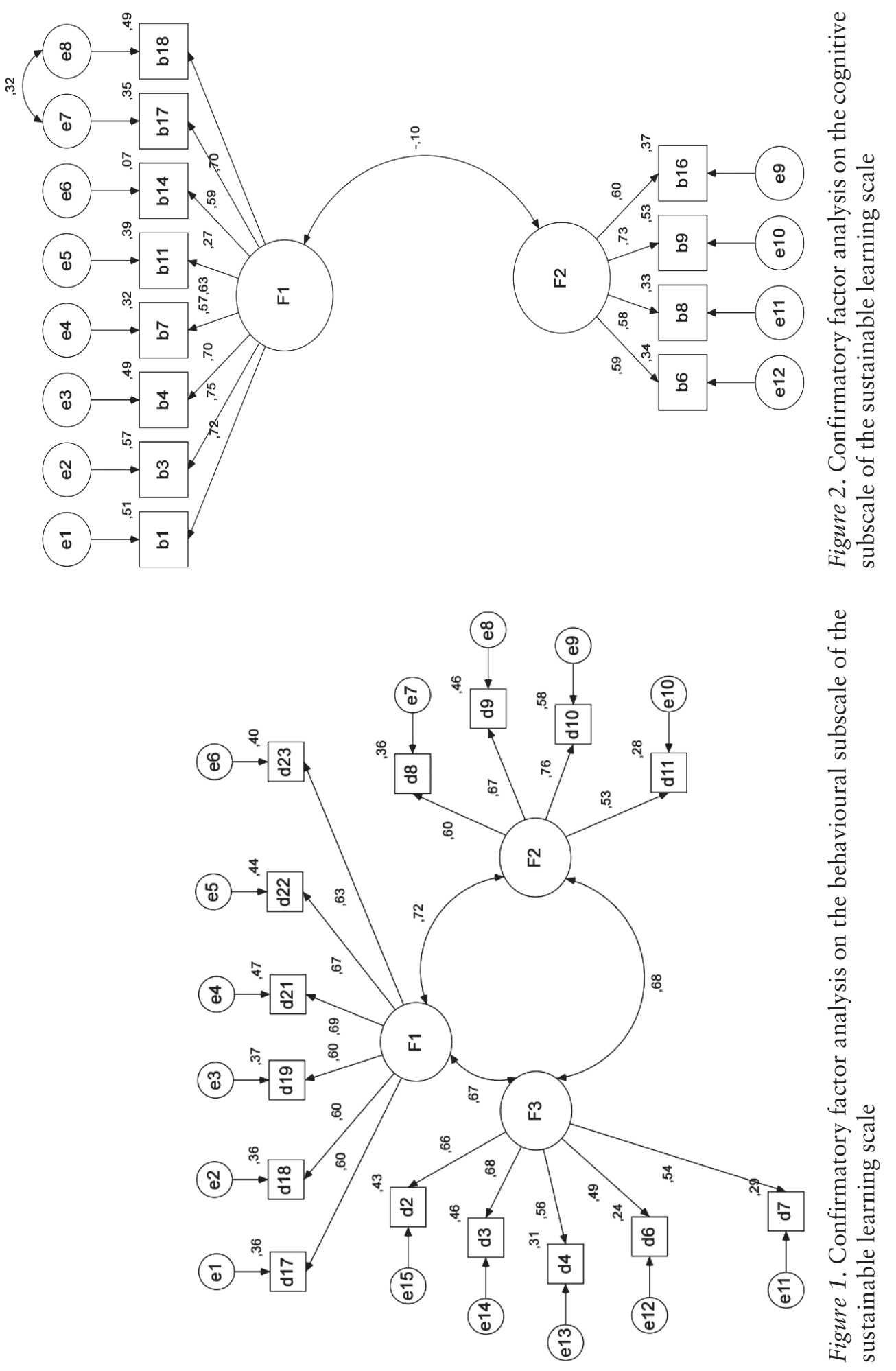
According to the results of the analysis, fit indices of the values obtained for model fit were $\mathrm{X} 2 / \mathrm{df}=4.700, \mathrm{TLI}=.905, \mathrm{CFI}=.925$ and $\mathrm{RMSEA}=.071$. In the literature, $\mathrm{X} 2 / \mathrm{df}$ is accepted below .50. Usually, .90 and above is interpreted as good for TLI and CFI while a RMSEA value between .050 and .080 represents good fit (Brown, 2006; Browne \& Cudeck, 1993; Sümer, 2000)

\section{Data Analysis}

After the "Sustainable Learning Scale" was administered to the participants of the study, the resulting data were analyzed through SPSS 17 and arithmetic mean, standard deviation, $\mathrm{t}$ test and one-way analysis of variance (One Way Anova) were used.

\section{Findings}

\section{Sustainable Learning Level of the High School Students}

To determine the high school students' sustainable learning level, the study calculated the arithmetic means and standard deviation of their scores on the "Sustainable Learning Scale" for the entire behavioural and cognitive subscales as well as their subdimensions. In addition, the item averages of the subdimensions were also calculated while interpreting the results since the number of items on the subscales was not equal. Findings are given in Table 2 and Table 3.

Table 2

Behavioural Subscale of the Sustainable Learning Scale for the High School Students

\begin{tabular}{lccccc}
\hline \multicolumn{1}{c}{ Subscales } & $\begin{array}{c}\text { Number of } \\
\text { Items }\end{array}$ & $\mathrm{n}$ & $\overline{\mathrm{x}}$ & SS & $\begin{array}{c}\text { Average of Items } \\
\text { in Subdimensions } \\
(\overline{\mathrm{x}} / \text { Number of Items })\end{array}$ \\
\hline "deep and broad learning" & 6 & 742 & 21.01 & 5.22 & 3.50 \\
\hline "learning by applying" & 5 & 742 & 15.63 & 4.08 & 3.13 \\
\hline "learning by updating" & 4 & 742 & 14.12 & 3.50 & 3.53 \\
\hline Total Scale & 15 & 742 & 50.75 & 10.61 & 3.38 \\
\hline
\end{tabular}

As is seen in Table 2, the arithmetic mean of the scores of the high school students comprising the sample group on the behavioural subscale was 3.38 . The arithmetic means of the students' scores on the subdimensions were found as follows: 3.50 for "broad and deep learning", 3.13 for "learning by applying" and 3.53 for "learning by updating".

Table 3

Cognitive Subscale of the Sustainable Learning Scale for the High School Students

\begin{tabular}{lccccc}
\hline \multicolumn{1}{c}{ Subscales } & $\begin{array}{c}\text { Number of } \\
\text { Items }\end{array}$ & $\mathrm{n}$ & $\overline{\mathrm{x}}$ & SS & $\begin{array}{c}\text { Average of Items } \\
\text { in Subdimensions } \\
(\overline{\mathrm{x}} / \text { Number of Items })\end{array}$ \\
\hline "learning for development" & 8 & 742 & 29.48 & 6.63 & 3.69 \\
\hline Learning for Exams & 4 & 742 & 13.28 & 3.23 & 3.32 \\
\hline Total Scale & 12 & 742 & 41.08 & 7.68 & 3.42 \\
\hline
\end{tabular}


The analysis of Table 3 demonstrates that the arithmetic mean of the scores of the students on the cognitive subscale was 3.42. The arithmetic means of the students' scores for the subdimensions "learning for development" and "learning not for passing exams only" were 3.69 and 3.32 , respectively.

\section{Independent Sample T Test Results for Determining Whether the Sustainable Learning Scale Scores Vary Based on Gender}

When identifying whether the high school students' scores on the sustainable learning scale varied based on gender variable, the study first performed One Sample Kolmogorov Smirnov Test to determine what the distribution of the data on both subscales was. The analysis indicated that the data followed a parametric distribution. Due to such distribution, the arithmetic means and standard deviations of the students' scores on the sustainable learning scale were calculated, and a t test was performed to find whether the variation between the arithmetic means based on gender variable was significant. The results for the behavioural and cognitive subscales of the sustainable learning scale and their subdimensions are presented in Table 4 and Table 5.

Table 4

Independent Sample T Test Results for Determining Whether the Behavioural Subscale Scores Vary Based on Gender

\begin{tabular}{lcccccc}
\hline Subscales & Number of Items & $\mathrm{n}$ & $\overline{\mathrm{x}}$ & $\mathrm{SS}$ & $\mathrm{t}$ & $\mathrm{p}$ \\
\hline \multirow{2}{*}{ "deep and broad learning" } & Female & 354 & 21.35 & 4.98 & \multirow{2}{*}{1.720} & \multirow{2}{*}{086} \\
\cline { 2 - 5 } & Male & 388 & 20.69 & 5.42 & & \\
\hline "learning by applying" & Female & 354 & 15.42 & 3.93 & \multirow{2}{*}{-1.294} & \multirow{2}{*}{.196} \\
\cline { 2 - 5 } & Male & 388 & 15.81 & 4.21 & & \\
\hline "learning by updating” & Female & 354 & 14.29 & 3.18 & \multirow{2}{*}{1.261} & \multirow{2}{*}{.208} \\
\cline { 2 - 5 } & Male & 388 & 13.97 & 3.77 & & \\
\hline Total Scale & Female & 354 & 51.07 & 9.65 & \multirow{2}{*}{.766} & \multirow{2}{*}{.444} \\
\cline { 2 - 5 } & Male & 388 & 50.47 & 11.43 & & \\
\hline
\end{tabular}

Table 4 reveals that the results of the t test performed to determine whether the variation between the arithmetic means was significant based on gender in all subdimensions of the behavioural subscale and the entire subscale indicated no statistically significant variation between the scores of the female and male students.

Table 5

Independent Sample T Test Results for Determining Whether the Cognitive Subscale Scores Vary Based on Gender

\begin{tabular}{|c|c|c|c|c|c|c|}
\hline Subscales & Number of Items & $\mathrm{n}$ & $\overline{\mathrm{x}}$ & SS & $\mathrm{t}$ & $\mathrm{p}$ \\
\hline \multirow[t]{2}{*}{ "learning for development" } & Female & 354 & 30.37 & 6.25 & \multirow{2}{*}{3.542} & \multirow{2}{*}{.000} \\
\hline & Male & 388 & 28.66 & 6.87 & & \\
\hline \multirow{2}{*}{$\begin{array}{l}\text { "learning not for passing } \\
\text { exams only" }\end{array}$} & Female & 354 & 13.24 & 2.95 & \multirow{2}{*}{-.303} & \multirow{2}{*}{.762} \\
\hline & Male & 388 & 13.31 & 3.47 & & \\
\hline \multirow[t]{2}{*}{ Total Scale } & Female & 354 & 41.47 & 6.91 & \multirow{2}{*}{1.325} & \multirow{2}{*}{.185} \\
\hline & Male & 388 & 40.72 & 8.32 & & \\
\hline
\end{tabular}


As is seen in Table 5, the results of the $t$ test performed to determine whether there was a significant variation between the arithmetic means in all subdimensions of the cognitive subscale and the entire subscale based on gender revealed a significant variation in "learning for development" subdimension scores based on gender, which was in favour of the female students. However, no significant variation was observed in "learning not for passing exams only" subdimension and the entire subscale based on gender variable.

\section{Results of One-Way Analysis of Variance (ANOVA) for Determining Whether the Sustainable Learning Scale Scores Vary Based on Grade}

To find whether the high school students' scores on the sustainable learning scale varied based on the grade variable, the study performed a one-sample Kolmogorov Smirnov test to determine the distribution of the data on both subscales. It was decided that the data followed a parametric distribution. Therefore, one-way analysis of variance was performed to determine whether the students' scores on the sustainable learning scale varied significantly based on grade.

The results of the one-way analysis of variance on the behavioural and cognitive subscales of the sustainable learning scale are given in Table 6 and Table 7.

According to Table 6, the result of the one-way analysis of variance (ANOVA) performed to determine whether the scores on the subdimensions of the behavioural subscale and the total subscale score showed a significant variance based on the students' grade revealed that the variation between the groups' arithmetic means was not significant for "broad and deep learning" $(F=1.99 ; p>.05)(F=1.99 ; p>.05)$, whereas there was a significant variation between the arithmetic means of the groups for "learning by applying" $(F=7.77 ; p<.001)$; "learning by updating" $(F=4.43 ; p<.01)$ and total subscale scores $(F=5.54 ; p<.01)$. To reveal from which groups such significant variation stemmed, the study performed post-hoc analyses.

First, the Levene's test was conducted to assess homogeneity of variance and it was found that the variances were homogenous. Thus, the Scheffe test was administered later. The result of this test showed that there was a variation in "learning by applying" subdimension between $9^{\text {th }}$ grades and $12^{\text {th }}$ grades in favour of the $9^{\text {th }}$ graders $(\mathrm{p}<.001)$ and between $10^{\text {th }}$ grades and $12^{\text {th }}$ grades in favour of the $10^{\text {th }}$ graders $(\mathrm{p}<.05)$; in "learning by updating" subdimension between $9^{\text {th }}$ grades and $12^{\text {th }}$ grades in favour of the $9^{\text {th }}$ graders $(\mathrm{p}<.05)$ and between $10^{\text {th }}$ grades and $12^{\text {th }}$ grades in favour of the $10^{\text {th }}$ graders $(\mathrm{p}<.05)$. As for the entire subscale, variation was found between $9^{\text {th }}$ grades and $12^{\text {th }}$ grades in favour of the $9^{\text {th }}$ graders $(\mathrm{p}<.01)$ and between $10^{\text {th }}$ grades and $12^{\text {th }}$ grades in favour of the $10^{\text {th }}$ graders $(\mathrm{p}<.05)$, and between $11^{\text {th }}$ grades and $12^{\text {th }}$ grades in favour of the $11^{\text {th }}$ graders $(\mathrm{p}<.05)$. However, no significant variation was found between the arithmetic means of other groups $(\mathrm{p}>.05)$. 
(

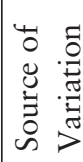

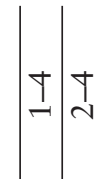

A

$\mid$\begin{tabular}{l|l} 
I \\
i
\end{tabular}

产 $\quad=\frac{\pi}{\pi}$

8

ठ

훙

aे

$\stackrel{\wedge}{\wedge}$

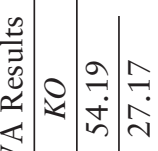

N

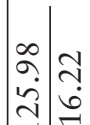

号

ปิ

品 m

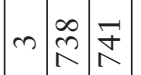

$\stackrel{n}{+}$

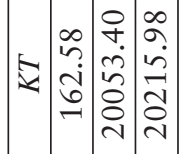

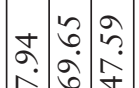

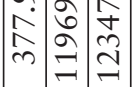

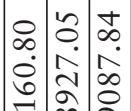

ำ $\stackrel{n}{7}$

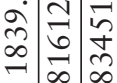

$\frac{\sqrt{0}}{\frac{2}{3}}$

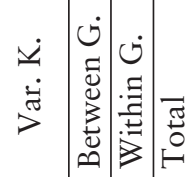

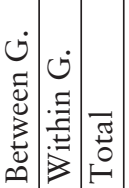

ن.

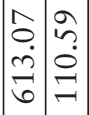

$m \stackrel{\infty}{ハ}$

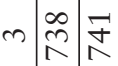

ธิ

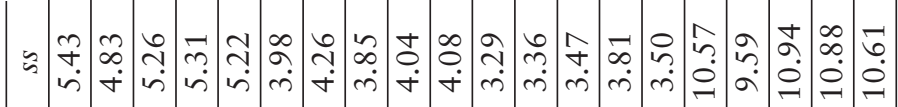

3

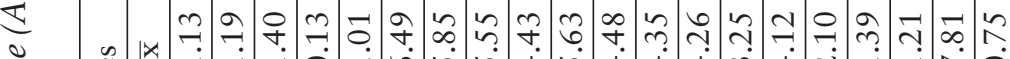

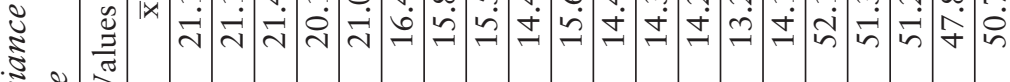

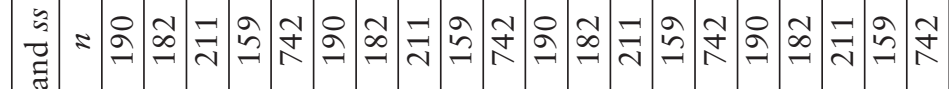

$\because$ ร

के 0

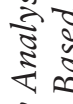

इे इ

$\geqslant \rho$

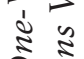

ก.

$\frac{2}{2} \frac{2}{2}$

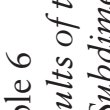

है:

$+$

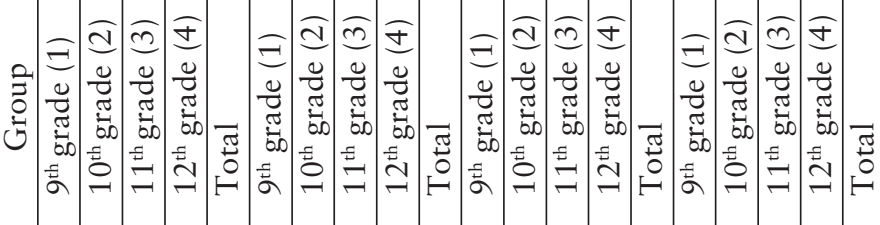

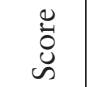

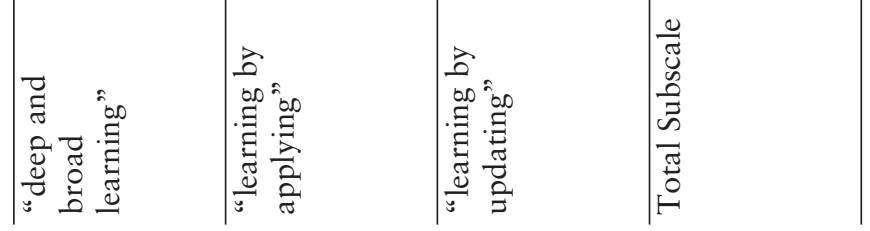




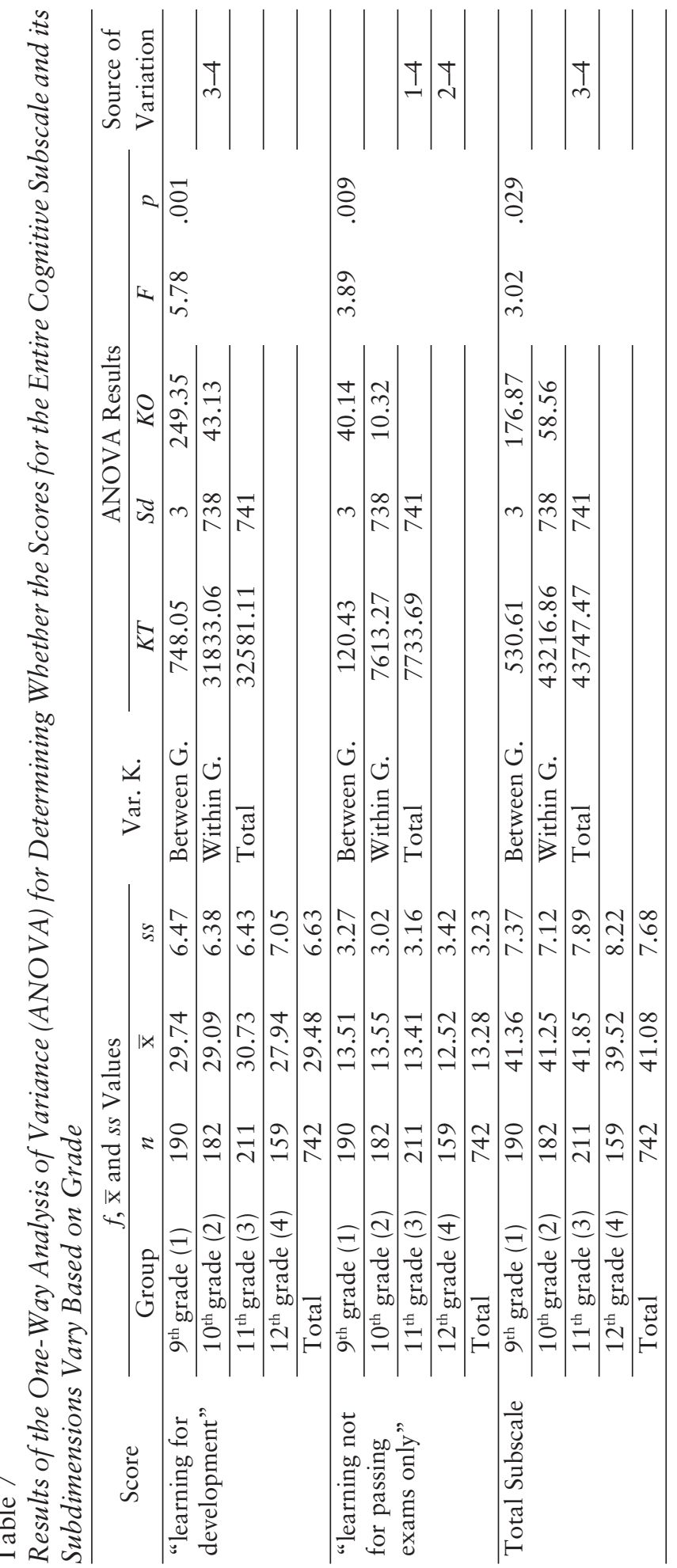


As is seen in Table 7, the result of the one-way analysis of variance (ANOVA), performed to see whether the scores on the subdimensions of the cognitive subscale and total subscale score varied significantly based on the grade variable, revealed a significant variation between the arithmetic means of the groups in "learning for development" subdimension score $(F=5.78 ; p<.01)$, learning not for passing exams only subdimension score $(F=3.89 ; p<.01)$ and total subscale score $(F=3.89 ; p<.01)$. To identify the source of such significant variation, the study performed post-hoc analyses. Therefore, first the Levene's test was conducted to assess homogeneity of variance, which indicated that the variances were homogenous. Thus, the study performed the Scheffe test this time. The result of the Scheffe test showed that the variation stemmed from the "learning for development" subdimension between $11^{\text {th }}$ grades and $12^{\text {th }}$ grades in favour of the $11^{\text {th }}$ graders $(\mathrm{p}<.01)$; "learning not for passing exams only" subdimension between $9^{\text {th }}$ grades and $12^{\text {th }}$ grades in favour of the $9^{\text {th }}$ graders $(\mathrm{p}<.05)$ and between $10^{\text {th }}$ grades and $12^{\text {th }}$ grades in favour of the $10^{\text {th }}$ graders $(\mathrm{p}<.05)$; and for the entire subscale, variation was found between $11^{\text {th }}$ grades and $12^{\text {th }}$ grades in favour of the $11^{\text {th }}$ graders $(\mathrm{p}<.05)$. Finally, there was no significant variation between the arithmetic means of other groups $(\mathrm{p}>.05)$.

\section{Discussion and Conclusions}

The high school students' score on the "Behavioural Subscale of the Sustainable Learning Scale" was 3.38 while their score on the "Cognitive Subscale" was 3.42. Thus, both scores were between 3 (neither agree nor disagree) and 4 (agree). In this case, it can be said that the students' behavioural and cognitive levels in sustainable learning were above medium level. It is considered that such a finding in the study resulted from the fact that the students have reached a certain maturity and hence, they understand the importance of learning for developing themselves as qualified individuals.

On the "Behavioural Subscale of the Sustainable Learning Scale", the participants scored 3.50 for "broad and deep learning"; 3.13 for "learning by applying"; and 3.53 for "learning by updating". According to these results, it can be concluded that the high school students" "broad and deep learning", "learning by applying" and "learning by updating" behaviours were above medium level. As for the "Cognitive Subscale of the Sustainable Learning Scale", the students scored 3.69 for "learning for development"; and 3.32 for "learning not for passing exams only". The scores for these subdimensions were between 3 (neither agree nor disagree) and 4 (agree). Here, it can be suggested that the students' "learning for development" and "learning not for passing exams only" behaviours were above medium level. An analysis of the subdimension scores on both subscales indicated that the students had lowest scores for the subdimensions "learning by applying" and "learning not for passing exams only".

It is considered that this finding stemmed from the students' tendency to use what they learn just as they are taught at school rather than applying those to new situations. Despite the fact that the Turkish education system has adopted constructivist approaches and developed curricula in line with these approaches in recent decades, the effects of traditional teaching-learning conception still seem to continue in the education system. Indeed, "learning not for passing exams only" subdimension that had the lowest score on the other subscale also supports this view. The findings obtained from other subdimensions demonstrated that the students had a tendency toward sustainable learning; however, one of the reasons for the abovementioned situation may be that the students' 
learning was mostly exam-oriented as they had a certain purpose and particularly because they need to take university entrance exam at high school. Thus, while many students who experience exam anxiety and want to become successful in this exam take pains to know what they learn to the letter and update such knowledge, they do not make any effort to put into practice what they learn and mostly engage in exam-oriented learning as result of an exam-oriented education system. In this context, it is believed that, students should be provided with opportunities to achieve proper sustainable learning, and also an educational understanding should be developed for not only becoming successful in exams but also for using learning at every stage of life.

A review of the literature in relation to the findings of this study indicated that the study conducted by Doğan, Kivrak and Baran (2004) found that the participating high school students could neither associate what they learned in biology course with daily life events nor interpret the causes and effects of events adequately. In a similar vein, another study conducted by Gürel, Güven and Gürdal (2003) reached the conclusion that the high school students could not use what they learned in physics course appropriately in daily life. The findings of these two studies are consistent with the finding of the present study that the high school students scored lowest in "learning by applying" subdimension on the sustainable learning scale. Also, the study conducted by Göçmençelebi and Özkan (2011) revealed that high school students reading magazines and newspapers and watching TV programs with scientific content as well as those owning a computer had higher scores in terms of establishing links between what they learned at school and daily life. Based on this finding, it was concluded that high school students who could use learning opportunities could associate what they learned at school with daily life at a higher level. Here, it can be suggested that the principles of sustainable learning are closely related. Similarly, the fact that the participants of the present study received similar scores on the subdimensions of the scale may result from the relationship between the principles of sustainable learning.

The study also examined the studies in the literature on high school students' reading habits as an indicator of "broad and deep learning", one of the principles of sustainable learning. The study conducted by Çeçen and Deniz (2015) found that high school students had a moderate attitude toward reading. It can be said that the students in the present study scored slightly above moderate for the "broad and deep learning" subdimension of the sustainable learning scale is consistent with the findings of the study conducted by Çeçen and Deniz (2015). The review of the relevant literature suggests that there are studies reporting that high school students have low levels of reading habits (Can, Türkylmaz and Karadeniz (2010); Üstten and Pilav (2014); Taşkesenlioğlu, 2013). Low level of reading habits in high school students in these studies is partly consistent with the finding of the present study that the students' score for "broad and deep learning" was moderate.

According to the analyses conducted to identify whether there was a significant variation in all subdimensions of the behavioural subscale of the sustainable learning scale and the entire subscale based on gender, no statistically significant variation was found between the scores of the female and male students. However, the scores on "learning for development" subdimension of the cognitive subscale showed a significant variance based on gender, which was in favour of the girls. No significant variation was observed in the subdimension "learning not for passing exams only" and the entire subscale based on gender. One of the reasons for such a finding may be that female students reach puberty earlier than their male counterparts and hence, they mature 
earlier. This may be one of the reasons for the variation in "learning for development" subdimension scores in favour of the girls because girls generally grow to maturity earlier both physically and mentally, and this may influence their perspective on life and events. In this scope, female students' tendency toward learning considering that it is necessary for their development rather than focusing on a situation or object (exam or a prize) may be one of the reasons for obtaining such a finding in the study. Moreover, gender stereotypes may also play a role in such a result. Thus, it is suggested that female students engage in a more sustainable learning style to develop themselves compared to male students, in order to eradicate negative stereotypes about women and achieve better social status in the future.

The analysis of the relevant literature indicates that a study conducted by Temizyürek, Çolakoğlu and Çoşkun (2013) found the rate of male high school students going to library to do homework was $41.9 \%$, and the rate of female students was $20.8 \%$. Also, the rate of female students going to library to borrow books like a novel, story etc. was $65.6 \%$ and the rate of male students was $47.7 \%$. In the same vein, the study conducted by Yeşilyurt (2006) revealed that female high school students had higher attitudes toward doing homework than male students. Another study conducted by Mau \& Lynn (2000) stated that female high school students had higher scores on doing reading homework. In support of this research, the study conducted by Younger \& Warrington (1996) stressed that female high school students were more determined and better organised in terms of doing homework.

It can be said that the findings in the literature demonstrate that female high school students use library not only for their lessons but also for learning aimed at development in general. This may be also that they have a better graph in terms of doing homework compared to their male counterparts. This is in line with the finding of the present study that the female students scored significantly higher in "learning for development" subdimension of the sustainable learning scale. In a similar vein, when high school students' answers, regarding the question about what affects their reading, were analysed in a study conducted by Üstten and Pilav (2014), it was found that the female participants preferred social activities more than the male students and adopted reading also as a means of socialization. Likewise, in support of the results of the present study which were in favour of the female students despite the lack of a significant variation in all subdimensions of the sustainable learning scale, a study conducted by Çeçen and Deniz (2015) reached the conclusion that there was no significant variation in female and male high school students' attitude toward reading, whereas female students had a higher attitude toward reading than their male counterparts. In addition, the study conducted by Deniz and Karbeyaz (2018) reported that male high school students experienced more burnout than female students in terms of feeling exhausted due to studying and doing homework, which is consistent with the finding of the present study that the female high school students had more sustainable learning skills than the male students.

According to the analyses conducted to see whether there was a significant variation in the scores for all subdimensions of the behavioural subscale of the sustainable learning scale and the entire subscale based on grade, no significant variation was found for "broad and deep learning" but significant variation was observed in "learning by applying", "learning by updating" and total subscale scores. This variation was found in "learning by applying" subdimension between $9^{\text {th }}$ grades and $12^{\text {th }}$ grades in favour of the $9^{\text {th }}$ graders, and between $10^{\text {th }}$ grades and $12^{\text {th }}$ grades in favour of the $10^{\text {th }}$ graders; in "learning 
by updating" subdimension between $9^{\text {th }}$ grades and $12^{\text {th }}$ grades in favour of the $9^{\text {th }}$ graders, and between $10^{\text {th }}$ grades and $12^{\text {th }}$ grades in favour of the $10^{\text {th }}$ graders. For the entire subscale, the variation was between $9^{\text {th }}$ grades and $12^{\text {th }}$ grades in favour of the $9^{\text {th }}$ graders and between $10^{\text {th }}$ grades and $12^{\text {th }}$ grades in favour of the $10^{\text {th }}$ graders, and between $11^{\text {th }}$ grades and $12^{\text {th }}$ grades in favour of the $11^{\text {th }}$ graders. Variation between the arithmetic means of other groups was not significant. As for the results of the analyses conducted to see whether there was a significant variation in the scores for all subdimensions of the cognitive subscale and the entire subscale based on grade, there was a significant variation in terms of the total subscale score and all subdimension scores. It was found that the variation was in "learning for development" subdimension between $11^{\text {th }}$ grades and $12^{\text {th }}$ grades in favour of the $11^{\text {th }}$ graders; in "learning not for passing exams only" subdimension between $9^{\text {th }}$ grades and $12^{\text {th }}$ grades in favour of the $9^{\text {th }}$ graders and between $10^{\text {th }}$ grades and $12^{\text {th }}$ grades in favour of the $10^{\text {th }}$ graders. Also variation was observed for the entire subscale between $11^{\text {th }}$ grades and $12^{\text {th }}$ grades in favour of the $11^{\text {th }}$ graders. No significant variation was found between the arithmetic means of other groups.

Being in an upper grade usually has a negative impact on sustainable learning for all subdimensions except "broad and deep learning". In Turkey, high school students take a university entrance exam in their final year, and this exam is very important for their future. Hence, they focus on exam-oriented learning, and try to learn everything to the letter and comprehensively. Thus, the lack of a significant variation between the students in different grades for "broad and deep learning" subdimension indicates that all students engaged in "broad and deep learning" in the same way. However, it is striking to find variation for both subscales in general as well as all other subdimensions particularly between $12^{\text {th }}$ graders and other students in favour of the latter. It is believed that the underlying reason for that is $12^{\text {th }}$ graders' tendency toward exam-oriented learning as they all would take university entrance exam.

A review of the relevant literature demonstrated studies investigating final year students' experiences of anxiety and burnout. The study conducted by Kutsal and Bilge (2012) found that the level of burnout in high school students increased with the advance in grade level. There are also other studies in support of the finding of the study conducted by Kutsal and Bilge (2012), which indicated that as high school students' grade level increased, their burnout and apathy levels also increased (Çapri \& Yedigöz Sönmez, 2013; Gündüz \& Özyürek, 2018; Yeni Palabıyık, 2014). Considering that sustainable learning is directly proportional to individuals' commitment to life, a parallel can be drawn between the studies in the literature and the finding of the present study suggesting that final year students scored significantly lower on the sustainable learning scale compared to the students in other grades. Moreover, another study conducted by Baştürk (2011) reported that the process of preparing for university had negative impacts on students' learning of mathematics. Students preparing for university learn only practical solutions instead of the logic of topics, which does not allow for broad and deep learning, learning by adjusting, and hence, sustainable learning. The study conducted by Kumandaş and Kutlu (2014) reported that successful students' communication with their family or friends declined as their grade level advanced, and they spent most of their time studying, which affects sustainable learning in a negative way.

The reason for the finding of the present study indicating that the level of sustainable learning was significantly lower among the final year students can be explained with 
the university entrance exam they were preparing for. In addition, the analysis of the studies on high school students in the literature also revealed that high school students' attitude toward mathematics declined as their grade level advanced (Eskici \& Ilgaz, 2019; Yenilmez \& Özabac1, 2003). This finding is ascribed to the university entrance exam that final year students prepare for. Gregor (2005) asserts that exam anxiety may affect students' learning negatively. The present study also comes to the conclusion that affects students' sustainable learning is affected in a negative way by exam anxiety.

\section{Recommendations}

Based on the findings of this research it can be recommended that Curriculums should be organized to take into account the principles of sustainable learning. Four principles of sustainable learning (deep and broad learning, learning by transferring, learning through dissemination, learning by strategizing) have been identified in this research. Teachers need better training in sustainable learning skills according to the principles of sustainable learning and appropriate practices for the realization of sustainable learning. Teachers would therefore give examples from daily life in their classes, and this means giving directions to learn the details of subjects for ensure deep and broad learning. Extracurricular activities (real world applications) would be included in the teaching process. Students would be given homework about daily life to provide learning by transferring. Different teachers or subject experts would therefore be invited to the courses. Different teaching methods and techniques are needed for use in the teaching process. Different teachers or subject experts and using of different teaching methods and techniques can provide learning by transferring, learning through dissemination. Measuring and evaluation methods that support sustainable learning must be developed. According to results of this research, upper grade students usually have negative impact on sustainable learning in all subscales except "broad and deep learning”, because final grade students have been prepared for central exams after graduation. Exam systems therefore must be revised to support sustainable learning.

Some recommendations have been made to increase research on sustainable learning in literature. Developed scales need to be applied to different places and different student groups. Qualitative studies related to SLS research are urgently needed. Sustainable learning levels of students must be compared with different characteristics. Sustainable learning principles put forward in this research can be developed by questioning.

\section{References}

Alberici, A., \& Di Rienzo, P. (2014). Learning to learn for the individual and society. Learning to Learn (pp. 103-120). UK: Routledge.

Anyolo, E. O., Kärkkäinen, S., \& Keinonen, T. (2018). Implementing education for sustainable development in Namibia: School teachers' perceptions and teaching practices. Journal of Teacher Education for Sustainability, 20(1), 64-81.

Artemeva, V. (2014). The future architects' attitude towards innovations in the context of sustainable development. Discourse and Communication for Sustainable Education, 5(1), 31-37.

Balcı, A. (2010). Glossary of explanatory educational management terms. Ankara: Pegem Press. 
Baştürk, S. (2011). Negative reflections of preparation process to the university entrance exam on students' mathematics learning. Hacettepe University Journal of Education, 40, 69-79.

Blewitt, J. (2004). Sustainability and lifelong learning. In J. Blewitt \& C. Cullingford (Eds.). The sustainability curriculum: The challenge for higher education (pp. 2442). Sterling, VA; Earthscan.

Can, R., Türkyılmaz, M., \& Karadeniz, A. (2010). Adolescent students' reading habits. Journal of Education Faculty of Ahi Evran University, 11(3), 1-21.

Charungkaittikul, S., \& Henschke, J. A. (2014). Strategies for developing a sustainable learning society: An analysis of lifelong learning in Thailand. International Review of Education, 60(4), 499-522.

Commission of the European Communities (2000). A Memorandum on Lifelong Learning. Brussels. Retrived from http://arhiv.acs.si/dokumenti/Memorandum_on_Lifelong_ Learning.pdf 13.04.2018

Çapri, B., \& Sönmez, G. Y. (2013). Investigation of burnout scores of high school students according to socio-demographic variables, psychological symptoms and attachment styles. Journal of Human Sciences, 10(2), 195-218.

Çeçen, M. A. ve Deniz, E. (2015). High school students' attitudes towards reading: The case of Diyarbakır. Mustafa Kemal University Journal of Social Sciences Institute, 12(30), 193-312.

Dash, G., \& Mohan, A. K. (2017). Education for sustainability: perception of teachers and practices in urban primary schools of Mysore. Gyanodaya: The Journal of Progressive Education, 10(2), 9-17.

Deniz, L., \& Karbeyaz, A. (2018). School burnout in vocational-technical high school students. Trakya Journal of Education, 8(4), 735-755. Retrieved from http://dergipark.gov.tr/trkefd/issue/39371/340592

Doğan, S., Kırvak, E., \& Baran, Ş. (2004). The levels of secondary school students making connection between daily life and the knowledge gained during biology lectures. Erzincan University Journal of Education Faculty, 6(1), 57-63.

Engin, M., Kör, H., \& Erbay, H. (2017). Turkish adaptation study of lifelong learning scale. Kastamonu Education Journal, 25(4), 1561-1572.

Eskici, M., \& Ilgaz, G. (2019). High school students and mathematics in the light of attitude, success and gender. Journal of Social Sciences of Mus Alparslan University, 7(1), 335-345. doi: 10.18506/anemon.422161

Franzenburg, G. (2017). Learning from the past for the future: How to make adult education sustainable. Discourse and Communication for Sustainable Education, $8(2), 57-65$.

Göçmençelebi, Ş. İ., \& Özkan, M. (2011). Does the use of technology and reading scientific publications affect the ability to relate science lesson knowledge to daily life a comparative study of turkish primary school student. Journal of Uludag University of Faculty of Education, 24(1), 287-296.

Gregor, A. (2005). Examination anxiety: Live with it, control it or make it work for you?. School Psychology International, 26(5), 617-635.

Gündüz, Z. B., \& Özyürek, A. (2018). The relationship between school burnout level and parents attitudes of high school students. Elementary Education Online, 17(1), 384-395. doi: 10.17051/ilkonline.2018.413786 
Gürel, Z., Güven, İ., \& Gürdal, A. (2003). Evaluation of skills of high school students in interpreting daily life events in lighth of the knowledge they learn in their physics lessons. Journal of Educational Sciences, 18, 65-78.

Hargreaves, A., \& Fink, D. (2003), The seven principles of sustainable leadership. Retrieved from http://jotamac.typepad.com/jotamacs_weblog/files/.pdf

Hargreaves, A., \& Fink, D. (2006). Sustainable leadership. San Francisco: Jossey-Bass. Hargreaves, A., \& Goodson, I. (2006). Educational change over time? The sustainability and nonsustainability of three decades of secondary school change and continuity. Educational administration quarterly, 42(1), 3-41.

Hipp, K. K., Huffman, J. B., Pankake, A. M., \& Olivier, D. F. (2008). Sustaining professional learning communities: Case studies. Journal of educational change, 9(2), 173-195.

Iliško, Dz. (2007). Teachers as agents of societal change. Journal of Teacher Education for Sustainability, 7, 14-27.

Ipiranga, A. S. R., \& Aguiar, M. M. S. (2014). Life, work and sustainable learning practices: a study on a small business network. BAR-Brazilian Administration Review, 11(2), 145-163.

Kabadayı, A. (2016). A suggested in-service training model based on Turkish preschool teachers' conceptions for sustainable development. Journal of Teacher Education for Sustainability, 18(1), 5-15.

Kumandaş, H., \& Kutlu, Ö. (2014). The risk factors caused by exams used for student selection and placement into higher education on the academic performance. Turkish Journal of Psychology, 29(74), 15-31.

Kutsal, D., \& Bilge, F. (2012). A Study on the burnout and social support levels of high school students. Education and Science, 37(164), 283-297.

Lambeir, B. (2005). Education as liberation: The politics and techniques of lifelong learning. Educational Philosophy and Theory, 37(3), 350.

Marton, F., \& Saljo, R. (1976). On qualitative differences in learning: Outcome and process. British Journal of Educational Psychology, 46(1), 4-11.

Mau, W. C., \& Lynn, R. (2000). Gender differences in homework and test scores in mathematics, reading and science at tenth and twelfth grade. Psychology, Evolution \& Gender, 2(2), 119-125.

McCombs, B. L. (1991). Motivation and lifelong learning. Educational Psychologist, 26(2), 117-127.

Mullins, S. B. (2018). Establishing a community of discourse through social norms. Discourse and Communication for Sustainable Education, 9(1), 5-17.

Pahad, A. (2012). Role of universities in life long learning for elderly people. Asian Journal of Home Science, 7(2), 600-604.

Palma, L. C., \& Pedrozo, E. Á. (2015). Complex matrix for the analysis of sustainable transformative learning: an assessment methodology of sustainability integration in universities. Assessment \& Evaluation in Higher Education, 40(6), 817-832.

Palmberg, I., Hofman-Bergholm, M., Jeronen, E., \& Yli-Panula, E. (2017). Systems thinking for understanding sustainability? Nordic student teachers' views on the relationship between species identification, biodiversity and sustainable development. Education Sciences, 7(3), 72.

Pepper, C., \& Wildy, H. (2008). Leading for sustainability: is surface understanding enough?. Journal of Educational Administration, 46(5), 613-629. 
Raji, M., \& Zualkernan, I. (2016). A decision tool for selecting a sustainable learning technology intervention. Journal of Educational Technology \& Society, 19(3), 306.

Reid, E., \& Horváthová, B. (2016). Teacher training programs for gifted education with focus on sustainability. Journal of Teacher Education for Sustainability, 18(2), 66-74.

Rorty, R. (1989) Contingency, irony, and solidarity. Cambridge: Cambridge University Press.

Salite, I. (2008). Educational action research for sustainability: Constructing a vision for the future in teacher education. Journal of Teacher Education for Sustainability, $10,5-16$.

Strachan, G. (2018). Can education for sustainable development change entrepreneurship education to deliver a sustainable future? Discourse and Communication for Sustainable Education, 9(1), 36-49.

Taşkesenlioğlu, L. (2013). A study about the reading habit of secondary school students. The Black Sea Journal of Social Sciences, 5(9), 261-273.

Temizyürek, F., Çolakoğlu, B. K., \& Çoşkun, S. (2013). Investigation of reading habits of the ninth grade students according to some variables. The Journal of Turkish Educational Sciences, 11(2), 114-150.

Tractenberg, R. E., FitzGerald, K.T., \& Collmann, J. (2017). Evidence of sustainable learning from the mastery rubric for ethical reasoning. Education Sciences, 7(2), 1-23. doi: 10.3390/educsci7010002 http://www.mdpi.com/2227-7102/7/1/2

Üstten, A. U., \& Pilav, S. (2014). A research on high school students' reading interests and habits. Journal of Theory and Practice in Education, 10(4), 764-782.

Wals, A. E., \& Jickling, B. (2002). Sustainability in higher education: From doublethink and newspeak to critical thinking and meaningful learning. International Journal of Sustainability in Higher Education, 3(3), 221-232.

Warburton, K. (2003). Deep learning and education for sustainability. International Journal of Sustainability in Higher Education, 4(1), 44-56.

Yeni Palabiyik, P. (2014). A study of Turkish high school students' burnout and proficiency levels in relation to their sex. Novitas-ROYAL. Research on Youth and Language, 8(2), 169-177.

Yenilmez, K., \& Özabacı, S.. N. (2003). An investigation on the relationship between mathematics and attitudes of mathematics on the level of maternity students. Pamukkale University Journal of Education, (14), 132-146.

Yeşilyurt, S. (2006). A study on high school students' attitudes towards biology assignments. Erzincan University Journal of Education Faculty, 8(1), 37-53.

Younger, M., \& Warrington, M. (1996). Differential achievement of girls and boys at GCSE: Some observations from the perspective of one school. British Journal of Sociology of Education, 17(3), 299-313.

Correspondence concerning this article should be addressed to Dr. Menekşe Eskici, Department of Educational Science, Kırklareli University, Kayalı Campus, TR 39000, Turkey. Email: menekseeskici@klu.edu.tr 